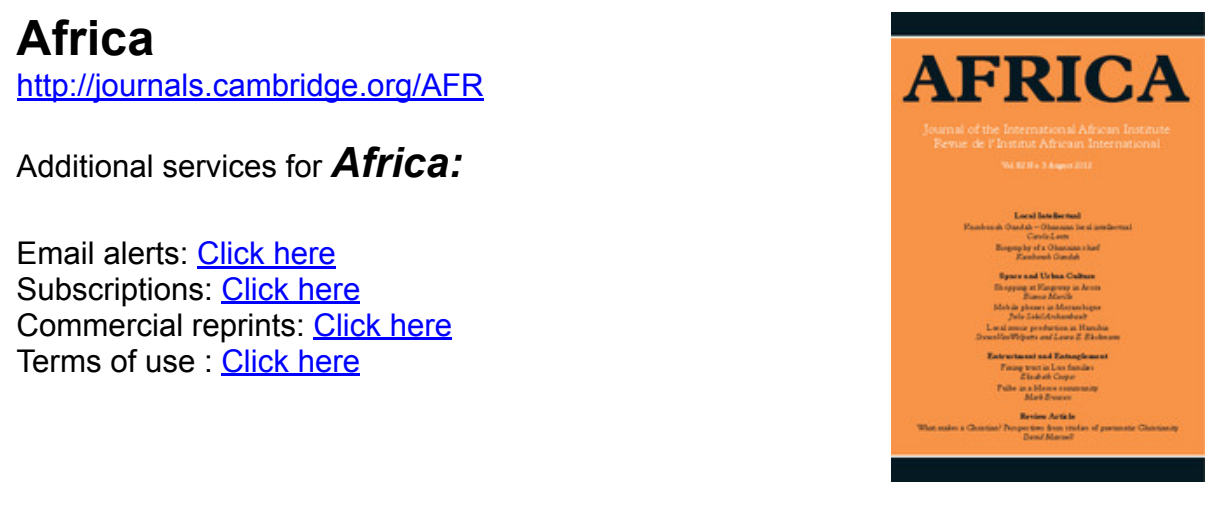

\title{
'TRAVELLING WHILE SITTING DOWN': MOBILE PHONES, MOBILITY AND THE COMMUNICATION LANDSCAPE IN INHAMBANE, MOZAMBIQUE
}

Julie Soleil Archambault

Africa / Volume 82 / Issue 03 / August 2012, pp 393 - 412

DOI: 10.1017/S0001972012000307, Published online: 27 July 2012

Link to this article: http://journals.cambridge.org/abstract_S0001972012000307

How to cite this article:

Julie Soleil Archambault (2012). 'TRAVELLING WHILE SITTING DOWN': MOBILE PHONES, MOBILITY AND THE COMMUNICATION LANDSCAPE IN INHAMBANE, MOZAMBIQUE. Africa,82, pp 393-412 doi:10.1017/S0001972012000307

Request Permissions : $\underline{\text { Click here }}$ 


\title{
'TRAVELLING WHILE SITTING DOWN': MOBILE PHONES, MOBILITY AND THE COMMUNICATION LANDSCAPE IN INHAMBANE, MOZAMBIQUE
}

\author{
Julie Soleil Archambault
}

When they were younger, Antonio, Manuel and João dreamt of one day owning a Land Cruiser. On their way home from school, they often talked about the journeys they would embark on and the girls they were hoping to meet along the way. Although all three have since graduated from secondary school, they still allude to the Land Cruiser. Every now and then, Manuel, who works as a security guard in the capital, phones the other two who are still in Inhambane and tells them before hanging up: 'Don't worry, I'm gonna bring the car home!' With a car, and not just any car, but the car best suited to navigate Mozambique's often treacherous roads, these young men dream of adventure. 'But in the meantime,' explains João, 'all we can do is travel sitting down ... all we can do is travel in our minds.'

Young people in southern Mozambique, like João, often articulate their everyday frustrations in the idiom of mobility. Other frequently heard examples include 'I'm tired of having to walk everywhere' [I wish I had money to hop on a minibus taxi/to buy a car] and 'I'm just sitting at home; I'm not doing anything' [I'm unemployed and going nowhere]. These expressions underscore a felt awareness of the way in which 'mobility... has been unequally disseminated' (McIntosh 2010: 344). In southern Mozambique, economic disparity is experienced as particularly painful given the legacy of socialism with its emphasis on equality and, more recently, post-war neo-liberalization and its promises of social mobility (Groes-Green 2010: 393; Sumich 2008: 122-3). If narratives of stasis emerge from the specificities of Mozambique's post-war, post-socialist economy, they also speak of much broader shared experiences. Indeed, various authors have recorded similar accounts in other parts of Africa (Hansen 2005; Langevang and Gough 2009; Mains 2007; Weiss 2005) and beyond (Jeffrey 2010), where young people, especially young men, are struggling to resolve the contradictions that stem from their 'expansive potential', notably as a result of access to education, amidst 'declining opportunities' (Weiss 2005: 107). Some show how educated young men not only express but also experience these frustrations in spatial terms (Adams 2009; Hansen 2005), while

JUlie SoleIL ARCHAmbault is a lecturer in African Anthropology at the University of Oxford. She received her PhD from the School of Oriental and African Studies (2010) and her MSc from the University of Montreal (2005). Based on an ethnography of mobile phone use in the city of Inhambane, southern Mozambique, her doctoral research examined secrecy practices in relation to the redefinition of gender and intergenerational relations under way in the post-socialist, postwar economy. Her current research focuses on the workings of the petty crime economy in southern Mozambique and reflects her broader interest in lifestyle aspirations and everyday experiences of young people living in contexts of uncertainty. Email: julie.archambault@africa. ox.ac.uk 
others focus on performances of mobility by those with little hope of actual mobility (Burrell 2009; McIntosh 2010). We hear of comparable experiences in locales beyond the African continent, telling of the global forces at play in these dynamics. For example, in his work on unemployed and universityeducated young men in India, Jeffrey (2010: 477) shows how frustrated aspirations, or what he calls 'spatio-temporal anxieties' are expressed through temporal idioms. There, young men describe themselves as waiting, as passing time, not unlike the three Mozambican friends who travel in their imagination 'in the meantime'. Whether they are articulated in temporal or spatial terms, these 'discursive metaphors' (Hansen 2005: 9) speak of expectations measured against a linear understanding of modernization (cf. Ferguson 2002) still salient - despite a fair share of cynicism - both in official discourse and in local imaginaries.

Thwarted dreams of mobility are also entwined with the recent spread of mobile phones. Throughout sub-Saharan Africa, the enthusiastic uptake of the technology came with promises of space-time compression and socioeconomic development (Donner 2008; Melkote and Steeves 2004; Slater and Kwami 2005). If mobile phone communication is understood to significantly transform experiences with time and space (Castells 2000; de Souza e Silva 2006; Ling and Pedersen 2005; Ling 2004; Maroon 2006), especially in contexts of constrained physical and social mobility (Burrell 2009; de Bruijn et al. 2009; McIntosh 2010; Porter et al. 2010), observers nonetheless tend to emphasize continuity over rupture and to situate mobile phones in relation to pre-existent forms of communication. For example, some have compared the phone to the talking drum (de Bruijn et al. 2009). Others have situated the appropriation of mobile phones in relation to local traditions of orality (Hahn and Kibora 2008). ${ }^{1}$

Based on fieldwork conducted in the city of Inhambane in southern Mozambique, this article examines the ways in which young men harness communication to express and address experiences of constrained physical and social mobility. It starts with an analysis of a highly valued form of oral communication-bater papo-that youth, especially young men, engage in on a daily basis and of which the Land Cruiser dream is but a taster. It then looks at technology-mediated communication with a focus on mobile phone practices. Tying these different forms of communication together is a profound desire to claim membership of, and to participate in, a world that remains elusive for most. However, if mobile phone communication builds on pre-existent forms of communication, it also takes on particular aesthetic qualities that testify to, rather than resolve, exclusion. In other words, I argue that, while helping bridge distances in significant ways, mobile phone communication nonetheless, and somewhat ironically, also betrays young men's immobility.

\footnotetext{
${ }^{1}$ Despite their mention of the respect due to the spoken word (p. 101), what Hahn and Kibora (2008) subsume under orality refers to oral communication in a context of high illiteracy rather than to an aesthetic form of oral exchange.
} 


\section{YOUNG MEN AND 'ALL THE NONSENSE' OF THE POST-WAR ECONOMY}

Situated on the Indian Ocean in southern Mozambique, Inhambane is a small provincial capital whose broad palm-lined avenues and decaying art deco buildings stand as reminders of more prosperous days. Inhambane was the southernmost port visited by Arab traders (Helgesson 1994: 102), though the area is believed to have received its name from Vasco da Gama who, on his first visit to the area in 1498, was warmly greeted in Gitonga by the local inhabitants: 'Baiete! Baiete! Bela nhambane, Bela nhambane' (Welcome! Welcome! Come inside our houses. Come inside our houses). Charmed by their hospitality, da Gama called the place Inhambane, The Land of Good People. These good people are also known as the Bitonga, a small group living in and around the city of Inhambane who share a common language, Gitonga, and now number around 170,000 (Gerdes 2001: 115). They are neighboured by Chopi populations to the south, as well as by Tswa groups to the north and west.

Despite these earlier contacts, it was only in the eighteenth century that the Portuguese established themselves permanently in the area and that a garrison was installed. This, in turn, consolidated the integration of the region within the slave trade and the broader 'littoral society' of the Indian Ocean (Alpers 2009: x). From then onwards, Bitonga history would be shaped by close, albeit parallel, proximity with Portuguese settlers. Not only did the inhabitants maintain a certain degree of isolation from broader political dynamics played out in the hinterland (Smith 1973: 580), but the Portuguese presence, along with access to assimilation status, also shaped Bitonga identity and linguistic practices ${ }^{2}$ in ways that I develop further below.

When Mozambique gained independence in 1975, after a war of liberation (1962-75) under the banner of the Frente de Libertação de Moçambique (Frelimo), most settlers fled; some even sabotaged the country's infrastructure upon their departure (Isaacman 1978: 29). Peace was short-lived, however, as in 1977 a nascent guerrilla movement known as the Resistência Nacional Moçambicana (Renamo) perpetrated its first attacks aimed at destabilizing the new regime. These were the start of a protracted war that eventually mutated into a vicious civil conflict, which was only resolved in 1992 following the signature of the peace accords. During the civil war (1977-92), the city remained a government stronghold whereas the hinterland was the scene of violent confrontations between Frelimo-led government forces and the foreign-backed Renamo forces (Cammack 1987; Vines 1991). In the late 1980s, the city's population more than doubled as many fled the war-ravaged countryside in search of protection. Following the resolution of the conflict in 1992, some of the refugees returned whence they had come, but many ended up staying in the city. Today, with just over 65,000 inhabitants, ${ }^{3}$ Inhambane's population

\footnotetext{
${ }^{2}$ In addition to lexical borrowing, various Portuguese grammar rules have also been integrated into Gitonga. For instance, the plural is often formed by adding the suffix /s/ instead of by adding noun class prefixes, as in other Bantu languages spoken in the province.

${ }^{3}$ According to the 2010 Population Census, <www.ine.gov.mz>, accessed 1 December 2010. Inhambane is also the name of the province.
} 
reflects the socio-linguistic diversity of the province. Despite its relatively high population density, Inhambane lacks the hustle and bustle along with the anonymity usually associated with urban life. As residents like to say: 'In Inhambane, there is no exit' (não há saida), an expression of capitulation that refers in part to the cul-de-sac location of the town, which was built on a peninsula, and to the city's lack of opportunities.

Since the resolution of the conflict, Mozambique has broken records in terms of economic growth, and went from one of the world's poorest countries to one praised as an African success story. ${ }^{4}$ The usual signs of economic progress are also increasingly visible. In Inhambane, a growing number of households now have electricity as well as running water, and cement houses are being erected here and there. In the city centre, shop windows display South African fashion, imported alcoholic beverages and the latest mobile phones. Whether Mozambique's economic growth has translated into the betterment of the lives of its citizens is, however, debatable and widely debated (Groes-Green 2010; Hanlon 2007). There are reports of high economic insecurity among the majority of the population, a rise in the percentage of people living below the poverty line, and an increase in socio-economic disparity (Hanlon 2007: 7).

All in their twenties, the young men I work with were born in troubled times. Like their parents who experienced post-independence euphoria (Isaacman 1978), they have similar expectations that come from a new beginning, in their case, consolidated peace and post-socialist neo-liberalization (West 2005). Like their parents, today's youth are also faced with a harsh reality, albeit a considerably less brutal one. In fact, many believe that they are suffering more than prior generations suffered (see also Sumich 2008: 122). Young people express nostalgia for 'the time of Samora', a common way of referring to the country's socialist period. ${ }^{5}$ Some even long for a mythical colonial past that most were too young to have experienced first-hand. Like the socialist period, the colonial period is remembered as one of order. To substantiate this yearning, one young man proudly told me that the security PIN on his phone was 1498, 'the year Vasco da Gama first came to Inhambane!' As they reflect on frustrated aspirations, young adults not only suggest that living conditions are deteriorating, as has been reported in other parts of the country (Sumich 2008), but also that peace adds insult to injury. For example, Samo, a young man who lost his right leg after stepping on a landmine, provided a poignant assessment of contemporary realities when he said: 'The war justified everything but now that we have peace, how are we supposed to make sense of all this nonsense?'

Part of the nonsense that Samo is referring to takes the form of young men's inability to live up to ideals of masculinity; a widespread phenomenon on

\footnotetext{
${ }^{4}$ In 2007, for example, the World Bank described Mozambique's economic growth as running at a 'blistering pace'; the same World Bank that had, less than two decades earlier, described the country as having returned to the Stone Age (Hanlon 2007: 1). In the same vein, a report published in 2006 suggests that, since the resolution of the conflict, Mozambique has seen a decrease in poverty, coupled with pro-poor development, and that all segments of society have experienced consumption growth (Arndt et al. 2006).

${ }^{5}$ Samora Machel was Mozambique's first President.
} 
which there is a large literature (Agadjanian 2005; Cole 2004; Cornwall 2003; Silberschmidt 2004; Vigh 2006). Historically, the ideal of the autonomous man who provides for his dependent women and children was consolidated by the integration of the region into the South African mining industry towards the end of the nineteenth century (First 1983). Throughout the colonial period, labour migration played a crucial socio-economic role in the reproduction of local communities (Arnfred 2001: 36). It also enabled young men to secure themselves the means to acquire wives, instead of having to depend on their elders. Working in the mines came to be seen as proof of maleness, and has been described as a rite of passage into manhood (Sheldon 2002: 3). It provided men with the opportunity to live up to mainstream ideas about masculinity and to address new forms of obligations, like paying taxes, and fulfilling new desires like owning a radio, a bicycle and a warm South African blanket. Also important was the idea that living up to mainstream ideals of masculinity was a process that took men to distant places, often for the better part of the year, where men gained not only capital but also knowledge and mind-opening experience.

However, following a reconfiguration of the political economy, young men are finding it increasingly difficult to live up to social expectations. To start with, the terms of the labour agreements between Mozambique and South Africa were seriously altered following independence in 1975 and the number of migrant labourers was drastically cut (Roesch 1992: 465). More important still, work migration has limited appeal to educated urban youth who instead covet jobs in the civil service. The rural exodus brought on by the war also increased pressure on urban centres like Inhambane, where residents are now faced with having to juggle limited employment opportunities and the rising cost of living, amidst a redefinition of gender hierarchies. Most young men in Inhambane live with relatives, often in women-headed households, and struggle to support themselves, let alone dependents. Most are either completing secondary school or have recently graduated. Yet, even those who follow this government-sanctioned path to economic security usually lack the capital necessary to secure formal employment or to start their own businesses. With a secondary school diploma in hand and limited job prospects, many describe themselves as 'not doing anything'. Free to occupy their time more or less as they please, young men enjoy sitting around with others who share their predicament and engaging in a form of oral exchange known as bater papo.

\section{EVERYDAY CONVERSATIONS AND MENTAL TRIPS}

\section{Status and the art of conversation}

Bater papo is a Brazilian expression young people use in reference to a form of oral exchange that could be translated as to chat, ${ }^{6}$ though with the risk of downplaying its social value. Harmonious social relations rest on respecting a hierarchy between generations, as well as between men and women, and a

\footnotetext{
${ }^{6}$ Literally, bater means to beat and papo a goitre or swollen neck.
} 
person's social worth is often measured by his or her respect for greeting etiquette. Older individuals are in fact regularly heard complaining about how youth no longer have time for greetings. In their defence, youth, even those involved in criminal pursuits, often speak of how they conscientiously go about greeting fellow residents as part of a strategy to claim recognition as respectful members of the community.

If mastering greetings is relatively straightforward, given its formulaic dimension, becoming proficient at conversation, on the other hand, is more of an art. Having good conversation is highly valued and being generous with words is arguably as important as being generous with material resources (cf. Abrahams 1983); so long as the words are good words. As in other forms of oral performances, competence in papo sessions is judged on eloquence, knowledge and creativity (cf. Vail and White 1991: 77). Papo can also be used to qualify a relationship. For instance, expressions like 'bato papo com elelela' (I converse with him/her) or 'é amigolamiga de papo' (he/she is a conversation friend), indicate the existence of a relationship that goes further than simple greetings. Papos can also acquire a life of their own, with participants referring to the most memorable conversations years after they occurred.

Young men in Inhambane regularly meet with the explicit intention to bater papo and commonly engage in meta-conversations in which they assess the quality of the papos in which they participate, as well as the conversation skills of particular individuals. They might conclude an encounter by saying something like: 'The papo was sweet, we should meet again', 'I feel relaxed now' or 'Talking like this really relieves stress'. During my stay in Inhambane, I organized a number of debates - a format of exchange with which students are familiar-on issues related to mobile phones. These proved invaluable if only because of the insight they offered on communication more generally, as they were usually followed by extensive discussions on the 'debate experience'.

Young people also reflect on the productive power that the appropriate papo can have on others. For example, men can seduce women with papo, in which case the expression used is latar uma dama com papo (to put a girl into a can or bottle with conversation). What is interesting about this expression is that it compares the powers of words with those of witchcraft, which is popularized as bending someone into submission by capturing their spirit into a container. It also links exclusivity with the control over women's mobility and rests on the often cited distinction between male and female 'love organs' that make 'men fall in love through their eyes and women through their ears'. Some women are, however, just as good at using papo to outwit the other sex. Women who take advantage of men under sexual pretences also rely on papo to get them out of uncomfortable situations. As a young woman explained, 'If you don't want to give sex, all you need to know is how to talk to close the man's eyes... all you need is the right papo'. There is, however, a fine line between cunning and deceit, and those who fail to deliver risk being accused of having or even being a papo furado (perforated talk).

Whereas most people can converse, not everyone has conversation (ter papo) and there are important differences between bater papo and falar ('to talk'). To talk is commonly used in the sense of 'to gossip' or 'to complain'. Accusing someone of talking a lot (você fala muito) is a great insult. Likewise, 'to quarrel', in Portuguese, is referred to as 'to make noise' (provocar 
barulho $).^{7}$ Falar is seen as the preserve of women, whereas men are portrayed as being better at papo. ${ }^{8}$ This gender divide builds on wider gendered life experiences. The domestic sphere in which women spend a lot of their time is believed to inhibit the creativity that promotes good conversation. ${ }^{9}$ In contrast, men have broader experiences beyond the household and are therefore seen as encountering more opportunities to acquire knowledge and develop creativity. For example, during colonial days, men who had not gone to the mines were seen as 'narrow-minded and ignorant provincials' (Marshall 1993: 60). The rationale behind this was not reduced to economic gain - although this played a large role in the equation - but also had to do with the acquisition of knowledge and mindopening experience.

The consumption of alcohol and marijuana is also seen as a key ingredient of 'sweet' papo. The neighbourhoods all have their baracas (small bars) which act as important social centres where people meet, gossip and pass on the latest news. Baracas are also venues of choice to bater papo. ${ }^{10}$ Drinking alone is frowned upon, a little like eating alone (cf. West 2005: 37), though for slightly different reasons. For one thing, drinks should be shared, but so should what comes out of drinking, that is, sociality and papo. In Antonio's words: 'You can't drink alone. It'll take you a long time to get drunk but when you're with someone, your imagination is triggered. Yeah, if you are on your own, you'll be preoccupied (concentrado).' Some have approached drinking sessions as arenas that allow and encourage the expression of resistance, as they provide time-out during which tensions are relieved and voiced under the cover of drunkenness (Akyeampong 1996; Cruz e Silva 2001: 37). It is more interesting, in my view, to look at drinking sessions not as a 'break in time' but rather as enhancing one's understanding of the workings of society, a perspective put forth by Willis (2002: 13-14) in his social history of alcohol in East Africa and one also voiced by my young interlocutors. Interestingly, the expression for having some money to contribute to the purchase of alcohol is ter idea, to have an idea. Drinking sessions almost inevitably include even a brief reflection on the social importance of the exchanges they lubricate. As a young man put it: 'The passers-by that see us sitting around drinking think that we are just wasting time. They don't realize that we are actually busy talking about important things.'

Many believe that alcohol consumption in Inhambane has decreased since the turn of the century. Some attribute this trend to a growing commitment to education among young people. Others argue that mobile phones form part of the equation as they channel limited resources. One young man succinctly explained

\footnotetext{
${ }^{7}$ Abrahams (1983) shows that in the West Indies being a gossiper was seen as 'wrong' but that having nothing at all to say was worse (p. 296). I would say that the same holds true in Inhambane.

${ }^{8}$ Timbila performances were also male-dominated: the performers were male and the issues discussed in the songs often revolved around male concerns. Among these, the fear that wives would commit adultery during their husband's absence in the mines was an important theme (Vail and White 1991).

9'Women's increased access to secondary education and the 'democratization of drinking' (van der Drift 2002) have contributed to the blurring of this gender divide.

${ }^{10}$ Young men explained, tongue-in-cheek, that the rising price of firewood was to blame for the move of evening storytelling from the yard to the bar.
} 
the process of prioritization he went through as a phone owner: 'Before when I got $100 \mathrm{MTn},{ }^{11} \mathrm{I}$ would spend it all on beer. Now I put 50 in my phone and I buy beer with the rest!' Apagnar rede (to catch network) is an expression usually used in situations when mobile network coverage is limited (on which more below). It also refers to the level of inebriation that stimulates good conversation. For example, if someone is particularly quiet in a drinking venue, others will say that 'he still hasn't caught network' (ainda não apagnou rede). Of course, excessive drinking can have the reverse effect and seriously impede speech, let alone conversation.

In addition to the gender differences mentioned above, rural-urban divides are also expressed through oratory competence. The young adults I worked with were fluent in at least one African language (Gitonga, Chitswa or Chichopi) and used Portuguese as a lingua franca.The different linguistic groups consider communication practices as important identity markers, with the Matswa and the Bitonga accusing each other of making noise (provocar barulho), and the latter more specifically accusing the Matswa of lacking sophistication. ${ }^{12}$ Prior to independence, a number of Bitonga became assimilados. This consisted of a privileged status which rested, in part, on one's mastery of the Portuguese language (Marshall 1993: 72). Claiming membership of the 'civilized world', to paraphrase Emidio, a man in his sixties, came to play an important part in Bitonga identity. Zuba, a Bitonga born in Inhambane in the 1960s, recalled being forced to speak Portuguese and forbidden to speak Gitonga while he was growing up. 'And we were told that the Matswa were inferior,' he explained, 'that they were people from the bush who didn't know how to speak Portuguese.' Individuals of Chopi origin, on the other hand, were usually described in less condescending terms. The Machopi are renowned for their excellence in several areas valued by the Bitonga: they are recognized as possessing special intellectual capabilities that bring them success in school, for example (see also Webster 1975). Today, Bitonga, Matswa and Machopi cohabit in relative harmony. They live in the same neighbourhoods, attend the same schools, pray in the same churches, drink in the same bars and engage in bater papo together. Bitonga nonetheless at times delve into this legacy when they use linguistic competence as a means to discriminate between themselves and the 'uncivilized from the bush'.

Lega Lega, a small market on the outskirts of the city that attracts crowds of young men and women on weekends, illustrates this rural-urban distinction beautifully. Agusto described it as a place where the 'matrekos da cidade' (losers of the city, mild negative connotation) meet the 'freaks do mato' (freaks of the bush, positive connotation), as the bars in Lega Lega are 'the last bars of the city and the first bars of the bush'. It was also described by city men as a place 'to get girls for a soft drink', that is, as a place where girls had lower material expectations than city girls. When young men from Inhambane made the trek to Lega Lega, they did not expect to have interesting conversation. 'You don't go to Lega Lega to bater papo!' Jhoker explained. Instead, they went there to drink, as well as for

\footnotetext{
${ }^{11}$ At the time, $100 \mathrm{MTn}$ was worth about $£ 2$. For comparison, the daily wages of unskilled workers were between 50 and $60 \mathrm{MTn} /$ day.

${ }^{12} \mathrm{Sr}$ Coche, a Chitswa speaker, talked about 'the Bitonga' thus: 'If you wake up and forget to leave money, the woman will appear at your work and shout it out, for everyone to know.'
} 
a change of scenery, and sometimes for the girls. In sum, ter papo is a quality that not only distinguishes men from women, at least in theory, but also urban from rural folk. The mastery of the art of conversation is seen as a prerequisite for anyone wishing to claim membership among the 'civilized', among those with some hope of social mobility.

\section{Travelling while sitting down}

The preferred papos are the ones that bring people to 'viajar sentado', to travel while sitting down. ${ }^{13}$ These are papos, like the Land Cruiser dream that the article started with, that trigger the imagination and that bring participants to travel mentally and away from reality, 'fora da nossa realidade'. Crapanzano (2004: 14) describes the imaginary as 'this realm that gives us an edge, at times wrenching and painful, at times relieving and pleasurable, on the here and now in all its vicious immediacy. It allows us to escape from the insistent pull of reality'. In other words, stories participate in the transgression of boundaries (de Certeau 1988: 129; see also Jackson 2006: 25).

Throughout my stay in Inhambane, I had the opportunity to partake in a number of papos in baracas, on street corners, at the beach and at people's houses. For example, on a numbingly hot summer afternoon when no one had the means to get to the beach, ${ }^{14}$ I found the usual crowd sitting around in the shade in front of Paito's house. Looking at the recently dug rubbish pit in his yard, Paito started his swimming pool 'trip' (viagem). He explained how we would build the first public pool in Inhambane. Everyone present took part in the conversation very seriously, contributing to the papo by asking Paito to discuss specific details of the project - 'Will there be a cover charge?' 'Which materials will we use?' - and approving his explanations. 'We'll build the place with local materials, like the South African lodge owners...they build marvels with material that we despise. Epa! How they travel these guys!' The conversation was done in the present tense, not the conditional, and for a good hour, we all 'travelled sitting down', in the shade of Paito's yard.

Other stories use humour to voice social critique (see Vail and White 1991: 112-54). Again at Paito's place, but this time on a rainy August afternoon, five young men from the neighbourhood were gathered in the sitting room. As a joint of marijuana was being passed around, Inocencio started recounting a story. It was a story about two 'romantic men', that he described as 'the kind who give flowers... you know the kind that have papo and know how to charm women'. On this occasion, however, our two romantics fell for a beautiful young woman known to chastise men. Hounded by both, the woman decided to play a trick on them by inviting both of them over to her house one evening. She told the first one to come at 9 p.m. and to hide in the big mortar used for pounding maize until she called him in. She told the other to arrive five minutes later and to beat the pestle

\footnotetext{
${ }^{13}$ Two famous Chopi composers explained to the musicologist Tracey that one had to 'dream' in order to compose music (Vail and White 1991: 123). They were probably referring to an experience similar to the one contemporary young men call viajar.

${ }^{14}$ The beaches are situated fifteen miles from the city and are connected by a regular minibus service. The price of a return trip to Tofo, the main beach, was $25 \mathrm{MTn}$ at the time, the same price as a pint of beer or just under half the daily wages of an unskilled labourer.
} 
very hard in order to signal his arrival. Everyone started laughing, so much so that Inocencio never managed to conclude the story. Instead, the other men present imagined themselves either in the mortar or wielding the pestle, and commented on how clever the woman was. 'Imagine you're there, hiding in the mortar, trying to be discreet', one said. 'Making sure you're not discovered by the girl's father,' said another with a chuckle. 'And holding a bouquet of flowers,' added a third, 'when suddenly this guy comes out of nowhere and starts beating you!' Everyone present agreed this was a fantastic story, one they would make sure to keep from their girlfriends, lest they be inspired to try out something similar.

The idea of travelling while sitting down reflects a lack of capacity to travel any other way. Had they the money to pay for the busfare to the beach, there might not have been a 'pool trip'. Papo sessions are, however, more than a performance of, or substitute for, mobility. Instead, they constitute socially important and enjoyable encounters that can also be seen as constitutive of a redefined masculinity (cf. Jeffrey 2010: 474, see also Mains 2007; Weiss 2005). Jackson's (2006: 18) reflection on storytelling provides useful insight. In his words, storytelling is

a coping strategy that involves making words stand for the world, and then, by manipulating them, changing one's experience of the world. By constructing, relating and sharing stories, people contrive to restore viability to their relationships with others, redressing a bias towards autonomy when it has been lost, and affirming collective ideals in the face of disparate experience. It is not that speech is a replacement for action; rather that it is a supplement, to be exploited when action is impossible or confounded. [My emphasis.]

Jackson chooses his words carefully and by suggesting 'supplement' rather than substitute (cf. Burrell 2009), he leaves space for the recognition of the aesthetic and social value of storytelling. When getting together to bater papo, men are actively creating new spaces, temporary realities that allow them to escape momentarily the frustrations they face in their daily lives. As Ginito, a young father of two, explained, 'Men never make enough money to make ends meet so instead of taking this little money home to my family, I end up going to the baraca where I'll find someone with whom I can bater papo and relieve my stress.' Papo sessions, especially mind-altering ones, are valued in their own right for the sociality they encourage and for the imagination they trigger. It is, however, a supplement - as young men nonetheless also aspire to more tangible forms of social and physical mobility.

\section{MOBILE PHONE COMMUNICATION}

Constricted experiences with mobility stand in contrast with narratives of forward and upward movement of the Mozambican nation captured in government speeches, advertising and popular music. ${ }^{15}$ The spread of mobile phones has been

\footnotetext{
${ }^{15}$ See, for example, MC Roger's hit song 'Moçambique sempre a subir (Mozambique always rising)' < http://www.youtube.com/watch?v=NdyudQOSMjk >, accessed 22 April 2012.
} 
portrayed as both indexing and facilitating this forward movement (Rungo 2007), and official discourse is explicit about the link between development and information and communication technologies (ICTs). Mozambique's landline provider, Telecomunicações de Moçambique, taps into this rationale and its slogan - 'Bringing people to communicate and develop Mozambique' - could not be more explicit. Though they are rather cynical, young men in Inhambane still believe that it is only a matter of time before they start reaping the benefits of the post-war economy. 'I won't feel [the comforts of] globalization myself, but hopefully my children will', is a comment I hear often. In the meantime, the phone acts as a tangible and conspicuous proof of membership in what my young informants like to call the 'globalized world'. As Antonio put it, 'The phone distinguishes those who live (os que vivem) from those who merely survive (dos que só sobrevivem).' To clarify, he added: 'You see, we collect phone numbers in case [we need to contact these people] but also to ascertain that they actually own a phone.' Like conversation skills, phone ownership, along with the display of certain phone practices, plays a fundamental part in young people's claim to a 'civilized' status.

\section{The urban communication landscape}

Mozambique's urban landscape is suffused with mCel's bright yellow and turquoise advertising, as well as with Vodacom's more sober palette of red, white and blue. Billboards bear the latest mobile phone offers and most of the city's businesses, including bars, restaurants, shops and markets, as well as decrepit walls, have received a fresh coat of paint from one operator or its rival. Both companies also reach the public by financing important television programmes, along with concerts and national holiday celebrations. Their omnipresence is such that one is constantly reminded that a mobile phone is the 'must-have' object of the moment (Myerson 2001: 3).

Handsets themselves are highly visible and audible features of the urban environment. In recent years, handsets have become readily available and tend to be relatively affordable. The thriving tourism industry in the nearby coastal areas also contributes to this market as a number of phones are 'left behind' by unwary tourists and injected into the pool of goods that are recycled within the community. Although phones are often tucked away in pockets or in the fold of capulanas (the piece of cloth women wear wrapped around their waist), they can also be seen cradled in brassieres and bulging out of vests or dangling from a cord and worn like a necklace. Phones are rarely switched off and, phone model permitting, ringtones are carefully chosen so as to impress. There are, however, some who prefer to keep their phone on silence in order to evade the scrutiny of others, especially boyfriends or girlfriends who might enquire about incoming calls and text messages (Archambault 2011).

New business ventures that have emerged in response to the spread of mobile phones also leave their mark on the urban landscape. Among these are small shops that sell phone accessories and that can resolve myriad phone issues, including unlocking foreign phones. A number of youths sporting the colours of one of the networks can be seen hovering around the main public areas where they sell recargas, airtime scratch cards that come in various denominations. Call boxes which have proliferated in parallel with the mobile phone industry and on 
which they rely for their existence also dot the main avenues of the city. Usually consisting of a phone with a unit counter placed on a small table with a bright parasol, these call boxes further contribute to the saturation of urban space with telecommunications.

Prior to the arrival of mobile phones, most people had only limited experience with telephones. When I asked how people used to communicate, I received one of two answers: 'We used to walk a lot more' or 'We would write letters'. Indeed, in Inhambane, mobile phones are rarely compared to fixed phones in part because Mozambique's landline infrastructure is poorly developed. ${ }^{16}$ Young and old remembered the many 'wasted journeys' they had undertaken as they would walk to someone's house or place of work only to find that the person in question had gone out. In fact, when rationalizing high mobile phone bills, some point out that travelling to another city in order to talk to someone would always be much more time-consuming and expensive than a phone call (see also de Bruijn et al. 2009; Slater and Kwami 2005). Illiteracy has severely impeded the use of letters. For example, the censor working in the 1940s described letters exchanged between migrants and their families as 'written by illiterates and very difficult to read' (Breckenridge 2006: 151). ${ }^{17}$ This should come as little surprise given that in 1960, 94.3 per cent of black Mozambicans were illiterate, which, even by regional standards, was extremely high (Cahen 2000). This said, though all were educated, my young informants saw little use in letter writing. When asked to give specific examples of when they had actually exchanged letters, they had to admit that they only faintly remembered having written or received a letter once or twice in their lives. Another important mode of long-distance communication is radio broadcast, which is used to transmit public messages directed at a wide audience, like funeral announcements. Various television programmes are also accompanied by messages usually sent by SMS or e-mail that scroll in a reserved area at the bottom of the screen. These messages combine the public dimension of messages transmitted over the radio but, unlike the latter, they tend to convey intimate content. In a context where most people have gone from no phone to mobile phone (cf. Orlove 2005) and where other modes of long-distance communication offer particular challenges, mobile phones can arguably be described as answering a 'real communication need' (Hahn and Kibora 2008: 93). Today, mobile communication lubricates the redistribution of remittances by facilitating coordination as well as by allowing those at the receiving end to play a more active role in the process (Archambault 2010). In Jhoker's words, 'Before you had to wait for your uncle to remember to send you money for school, now you can call him to remind him.' Like other modes of communication, however, mobile phone communication has its fair share of drawbacks, ${ }^{18}$ not least among them economic costs, the topic of the following section. Some problems are linked to

\footnotetext{
${ }^{16}$ The penetration of landlines stood at 0.39 per cent in 2007 (Interview with Massingue Apala of the Instituto Nacional das Communicações de Moçambique, Autoridade Reguladora dos Sectores Postal e Telecommunicações (INCM), Maputo, 13 November 2007).

${ }^{17}$ Unlike South African migrant workers, who were actively involved in writing letters by the early twentieth century, it was only in the 1940s that migrants of Mozambican origin started exchanging letters (Breckenridge 2006: 151).

${ }^{18}$ For an analysis of the social costs of the recent spread of mobile phones in Inhambane, see Archambault 2011.
} 
the actual physicality of phones ${ }^{19}$ and to the unreliability of network coverage, which is patchy and mainly restricted to urban centres and sections of the national highway. A young man once compared network coverage to a thong underwear: 'Now you see it,' he said, holding his phone upright to symbolize a woman and then rotating it 180 degrees to expose her backside, 'now you don't!' I captured another colourful image at an ancestor worship ceremony I attended with one of my informants in a district of Inhambane. Dozens of mobile phones were hung from the branches of a large cashew tree 'to catch network [coverage]' (apagnar rede). Under what reminded me of a Christmas tree, some cooked while others enjoyed the shade and, in order to attend the beeps and rings that punctuated the drumming, one had to carefully steer clear of the fires, while remaining at the right height not to lose rede (network coverage); precious rede!

\section{Feeding phones}

'We feed mobile phones but they're not even persons!' Such a self-critical comment establishes a parallel between mobile phones and dependants. It also implicitly hints at young men's highly debated inability to live up to the ideal of the autonomous provider. As I discuss below, phone etiquette also rests on this ideal. Unlike men, women often find it difficult to estimate how much they spend on phone credit. In fact, I have yet to come across a woman who had given up her phone for economic reasons, whereas it is not uncommon for men to 'take a break' from phone ownership when going through particularly difficult times.

Overall, communication needs are experienced as largely unfulfilled and, like money, phone credit rarely lasts very long. When youths top up their phones, it is usually either for a specific purpose or because they have just received money and want to buy credit before spending it on other things. Although payas-you-go makes phone communication affordable, it nonetheless remains very expensive, especially for those without a regular source of income. As a response to prohibitive costs, users have developed various strategies to reduce phone bills. For example, they opt for per-second billing, which is considerably more advantageous than per-minute billing for short calls. Some even have their thumb on the hang-up key while calling in order to terminate calls more swiftly. Clients of both mCel and Vodacom can also call three pre-selected contacts

\footnotetext{
${ }^{19}$ Most people own used phones that they either bought on the second-hand market, 'found' on a night out, or received as a gift. On some handsets, the numbers are no longer visible from overuse, thus making texting a real art. Batteries are often faulty and, as a result, phones tend to require charging more often than new handsets would. Given limited access to electricity, this is particularly problematic. Indeed, recharging one's phone often calls for resourcefulness. If rural residents resort to car batteries and solar panels, these solutions are considered inappropriate in an urban context. Everyone aspires to have electricity at home in the (near) future and acquiring an alternative source of energy would therefore only further distance one from attaining that objective. In the suburbs of Inhambane, the number of households connected to the national grid is growing thanks to the implementation of a pay-as-you-go system that renders it more affordable. Those without access to electricity at home usually recharge phones at school or at the neighbour's house, but this involves a number of downsides, namely missed calls, the risk of handset or phone credit theft, and the shame that comes from not having electricity.
} 
free of charge between midnight and 4 a.m. ${ }^{20}$ In addition, there are various ways to communicate free of charge, or to adopt what Hahn and Kibora (2008: 104) call a 'zero budget strategy'.

\section{Bips and heartbeats}

Every day comes with a fresh allowance of ten free 'liga-me' (call me) messages, which are free messages asking the receiver to call the sender. In addition, one can also request a return call more informally by sending a bip, a practice that involves hanging up before the receiver picks up. Bips are unlimited, so long as the sender has a minimum of credit to actually place a call and they come with the risk of this credit being 'eaten' if the receiver answers before the sender hangs up. Both liga-me and bips can be used for the same purpose - asking to be called back - but a bip can also be used as a signal that requires a response other than a phone call. For example, a bip often means 'I've arrived'. In other cases, bips can take on a more complex meaning and the expected response will usually be pre-established between the sender and the receiver. For instance, for Antonio and some of his classmates, two successive bips is a rallying call to meet at the nearby palm wine bar. Or, to give another example, close friends regularly send each other bips, as a 'sign of life' (sinal de vida), like a heartbeat, every day when they wake up. In such cases, both parties communicate free of charge.

When costs are incurred, that is, when calls are actually placed, men are usually expected to pick up the tab when communicating with women. ${ }^{21}$ Young women send bips to lovers and suitors on a regular basis in the hope of being called back and often with the intention of placing requests for specific things. ${ }^{22} \mathrm{Men}$, for their part, admit to usually phoning when they receive a bip, and many report feeling uneasy in situations when they have no phone credit to do so. It is in fact striking how young men describe their experiences with mobile phones as stressful. These gendered rules are often broken depending on the specificities of the situation, but they nonetheless guide and serve to gauge actual phone practices (Archambault 2010: 95). Some men are more subject to requests

\footnotetext{
${ }^{20}$ In 2008, both operators started charging $0.029 \mathrm{MTn} /$ minutes for these calls. Although still very cheap, the fee means that this option is no longer available to those without the means to acquire airtime. On a follow-up research trip in 2009 , I found that young people no longer took advantage of this almost free window. 'It's annoying to get woken up in the middle of the night', Hernane explained in a conversation with Jhoker, who added that they had tired of the novelty of free nocturnal calls.

${ }^{21}$ Equals like friends of the same sex, or siblings in similar economic situations, are supposed to cover the cost of their calls themselves and a man who sends bips, in the hope of being called back, is likely to be ridiculed. When transposed to phone use, generational hierarchies yield slightly more ambiguous rules. Younger individuals are expected to show deference towards older individuals, whether kin or not, and are expected to serve them. As minors, however, they are also dependants. Some expressed resentment towards 'cheeky' younger relatives who would send them bips, whereas others were generally called back when requesting older relatives to do so. In other words, intergenerational phone etiquette tends to be overshadowed by other considerations, including gender and residence. Overall, individuals living in urban settings are usually expected to cover the costs of communicating with relatives residing in rural areas.

${ }^{22}$ It was not uncommon for some to exceed their daily allowance of 'call me' messages. Countless times, young girls asked to use my phone to send a 'call me'. In most cases, the receiver would reply by calling my number, despite not knowing the identity of the person requesting to be called back.
} 
than others. For example, Mikas, an employed and older man, often complained about women taking advantage of him, of 'enslaving' him, as he called it. One day in my company, he received a phone call from a young woman. Already imagining the motive of her call, he answered with his volume turned up. The woman went straight to the point and asked him for phone credit. After hanging up, Mikas started laughing: 'I'm a fool, I'm stupid', he said, 'I will give her credit and then she will use it to phone another man!' He then told me about a girlfriend who had contacted him recently to let him know that someone had stolen all her clothes. Mikas explained that he gave her money, along with an 80 MTn top-up, so that she would phone him and have no excuse for not doing so. She did find excuses, though, and as Mikas concluded, half-jokingly, 'Whenever I phone her, she is either on her way to church or to school!' Men who fall 'victim' to requests placed via the phone are mostly older employed men like Mikas. This said, younger men are nevertheless also regularly asked to reply to bips, as well as to supply smaller things like hair extensions, lunch money, or phone credit. For younger unemployed men who only get money sporadically, even the small gesture of replying to a bip may, at times, be beyond their reach. Bipping not only puts added pressure on young men, it also makes their hardship more apparent. As Hernane pointed out, 'A girl will think: "What can this man offer me if he can't even call me back?".' In other words, maleness goes from being perceived as a social process to being experienced as volatile and hyper-exposed to the vagaries of everyday life.

\section{Texting 'beautiful messages'}

Text messages are another way to keep costs low and most top-ups include a number of free texts. Beyond economics, part of the appeal of text messages lies in their materiality. ${ }^{23}$ Texts that are expressive rather than informational are sent and received like gifts that can be kept and read to activate memories (cf. Lin and Tong 2007). Before going to bed, young people like to go through their inbox and read their saved messages. Many also express being heartbroken when having to delete 'beautiful messages' (mensagens bonitas). I have discussed elsewhere how this was a soft spot that often led to confrontation (Archambault 2011). As Gina explained, 'Sometimes you receive a very nice message, and it doesn't come from your boyfriend, but still you start travelling with the message and then your boyfriend grabs your phone and starts beating you: "How come you have this message here, who is this message from?" You see, when you were just liking the message!'

The phone analyses I carried out revealed that the greater part of these messages were highly formulaic and often written by professional message writers in the business of composing religious, romantic and/or humorous messages for wider circulation. Many were also gender-neutral and could therefore be passed on from a man to his girlfriend who could then send it to another man, and so on. For example, one of my female informants' inbox contained over a

\footnotetext{
${ }^{23}$ If illiteracy impedes letter writing, it also affects text messaging. All the youths I worked with know how to send and receive text messages, but they occasionally communicate with individuals who have limited literacy skills as well as minimal knowledge of the various functionalities of specific handsets.
} 
dozen such pre-fabricated or 'Hallmark messages' (Ellwood-Clayton 2006: 360). One of them, sent by her employer, said that she would affect the results of the Population Survey underway at the time through being counted in many houses, thus alluding to her reputation for being a bit of a player. A number of my female informants received the same message around that time.

Phone communication tends to espouse different aesthetic qualities to those that characterize papo sessions and, if anything, resembles more the greetings discussed earlier. A large part of the mobile phone communication that takes place in Inhambane is in fact either coded-thanks to bips and 'call me' messages - or formulaic. Although some use their phones to bater papo, usually at night when calls are free of charge, most of the papos that trigger the imagination are performed face to face.

\section{CONCLUSION}

Mobile phone communication has the potential to shift, albeit in contested and imperfect ways, the interface between daydreams and reality, between mental trips and trips in the material world, by expanding the possible (cf. Horst and Miller 2006) in more palpable ways than papos do. However, as Larkin (2008: 235) insightfully summarizes the point, 'as the speed of ... life increases, so too does the gap between actual and potential acceleration, between what technologies can do and what they do do' (emphasis in original). Looking at the relationship between mobile communication and mobility more specifically, McIntosh (2010: 344) suggests that, though mobile phones may not actually promote physical mobility, they nonetheless open up a space for what she calls 'the enactment of imagined global identities' ${ }^{24}$ Such an analysis also holds true in Inhambane, where mobile phones are used to play on experiences of stasis by providing a conspicuous avenue for the display of membership of and participation in the world of those with some hope of social mobility. In many cases, however, and especially when it comes to communication between men and women, mobile phones do just the opposite by revealing, through unanswered bips and other requests, that it is mere pretence and that most are actually going nowhere. Indeed, young men are always on the qui vive as they never know when their masculinity will be probed and whether they will be able to call back the next time they are sent a bip. It is little wonder, then, that they would describe their experiences with mobile phones as stressful. Travelling while sitting down, in turn, helps alleviate stress but, as Mozambique celebrates twenty years of peace later this year, it only fleetingly addresses frustrated experiences with mobility and the more general 'incohesions' (Mbembe and Roitman 1995: 338) of the post-war economy.

\section{ACKNOWLEDGEMENTS}

The article is based on the author's doctoral research in Anthropology at the School of Oriental and African Studies, University of London. The research was funded by the Social

\footnotetext{
${ }^{24}$ McIntosh (2010) suggests that mobile phone practices can be seen as performances of mobility. She argues that linguistic choices in text messaging speak of Giriama attempts at redefining themselves in a way that collapses the boundaries between the local and the global.
} 
Sciences and Humanities Research Council of Canada, as well as by the Overseas Research Student Scheme, UK, and the Central Research Fund, University of London. Earlier versions of this article were presented to the Africa Seminar at the London School of Economics and to the Anthropology Seminar at the University of Oxford. I am grateful to the participants and reviewers for their comments.

\section{REFERENCES}

Abrahams, R. D. (1983) The Man-of-Words in the West Indies: performance and the emergence of Creole culture. Baltimore: Johns Hopkins University Press.

Adams, M. (2009) 'Playful places, serious times: young women migrants from a peri-urban settlement, Zimbabwe', Journal of the Royal Anthropological Institute 15 (4): 797-818.

Agadjanian, V. (2005) 'Men doing "women's work": masculinity and gender relations among street vendors in Maputo, Mozambique' in L. Ouzgane and R. Morrell (eds), African Masculinities: men in Africa from the late nineteenth century to the present. New York NY: Palgrave Macmillan.

Akyeampong, E. K. (1996) Drink, Power and Cultural Change: a social history of alcohol in Ghana, c. 1800 to recent times. Portsmouth NH: Heinemann.

Alpers, E. A. (2009) East Africa and the Indian Ocean. Princeton NJ: Markus Wiener Publishers.

Archambault, J. S. (2010) 'La fièvre des téléphones portables: un chapitre de la "success story" mozambicaine?', Politique africaine 117: 83-105.

(2011) 'Breaking up "because of the phone" and the transformative powers of information in southern Mozambique', New Media and Society 13 (3): 444-56.

Arndt, C., R. C. James and K. R. Simler (2006) 'Has economic growth in Mozambique been pro-poor?', Journal of Southern African Economies 15 (4): 571-602.

Arnfred, S. (2001) Family Forms and Gender Policy in Revolutionary Mozambique (1975-1985). Bordeaux: Centre d'études d'Afrique noire.

Breckenridge, K. (2006) 'Reasons for writing: African working-class letterwriting in early-twentieth-century South Africa' in K. Barber (ed.), Africa's Hidden Histories: everyday literacy and making the self. Bloomington and Indianapolis IN: Indiana University Press.

Burrell, J. (2009) 'Could connectivity replace mobility? An analysis of Internet café use patterns in Accra, Ghana' in M. de Bruijn, F. Nyamnjoh and I. Brinkman (eds), Mobile Phones: the new talking drums of Africa. Leiden: Langaa and African Studies Centre.

Cahen, M. (2000) 'L'état nouveau et la diversification religieuse au Mozambique, 1930-1974', Cahiers d'études africaines XL (2) (158): 309-49.

Cammack, D. (1987) 'The "human face" of destabilization: the war in Mozambique', Review of African Political Economy 14 (40): 65-75.

Castells, M. (2000) The Rise of the Network Society. The information age: economy, society and culture. Oxford: Oxford University Press.

Cole, J. (2004) 'Fresh contact in Tamatave, Madagascar: sex, money, and intergenerational transformation', American Ethnologist 31 (4): 573-88. 
Cornwall, A. (2003) 'To be a man is more than a day's work: shifting ideals of masculinity in Ado-Odo, Southwestern Nigeria' in L. A. Lindsay and S. F. Miescher (eds), Men and Masculinities in Modern Africa. Portsmouth NH: Heinemann.

Crapanzano, V. (2004) Imaginative Horizons: an essay in literary-philosophical anthropology. Chicago IL: University of Chicago Press.

Cruz e Silva, T. (2001) Protestant Churches and the Formation of Political Consciousness in Southern Mozambique (1930-1974). Basel: P. Schlettwein Publishing.

de Bruijn, M., F. Nyamnjoh and I. Brinkman (2009) 'Introduction' in M. de Bruijn, F. Nyamnjoh and I. Brinkman (eds), Mobile Phones: the new talking drums of Africa. Leiden: Langaa and African Studies Centre.

de Certeau, M. (1988) The Practice of Everyday Life. Berkeley CA: University of California Press.

de Souza e Silva, A. (2006) 'Interfaces of hybrid spaces' in A. Kavoori and N. Arceneaux (eds), The Cell Phone Reader: essays in social transformation. New York NY: Peter Lang.

Donner, J. (2008) 'Research approaches to mobile use in the developing world: a review of the literature', The Information Society 24 (3): 140-59.

Ellwood-Clayton, B. (2006). 'All we need is love-and a mobile phone: texting in the Philippines', 'Cultural Space and Public Sphere in Asia', < http://asiafuture. org/csps2006/50pdf/csps2006_6c.pdf>, accessed 2 June 2010.

Ferguson, J. (2002) 'Of mimicry and membership: Africans and the "new world society"', Cultural Anthropology 17 (4): 551-69.

First, R. (1983) Black Gold: the Mozambican miner, proletarian and peasant. Brighton: The Harvester Press.

Gerdes, P. (2001) 'Exploring plaited plane patterns among the Tonga in Inhambane (Mozambique)', Symmetry: Culture and Science 12 (1-2): 115-26.

Groes-Green, C. (2010) 'Orgies of the moment: Bataille's anthropology of transgression and the defiance of danger in post-socialist Mozambique', Critique of Anthropology 10 (4): 385-407.

Hahn, H. P. and L. Kibora (2008) 'The domestication of the mobile phone: oral society and new ICT in Burkina Faso', Journal of Modern African Studies 46 (1): 87-109.

Hanlon, J. (2007) 'Is poverty decreasing in Mozambique?', paper presented at the Inaugural Conference of the Institute of Social and Economic Studies, Maputo.

Hansen, K. T. (2005) 'Getting stuck in the compound: some odds against social adulthood in Lusaka, Zambia', Africa Today 51 (4): 3-16.

Helgesson, A. (1994) 'Church, State and People in Mozambique'. PhD thesis, Uppsala University.

Horst, H. A. and D. Miller (2006) The Cell Phone: an anthropology of communication. Oxford: Berg.

Isaacman, A. (1978) A Luta Continua: creating a new society in Mozambique. Binghamton NY: State University of New York.

Jackson, M. (2006) The Politics of Storytelling: violence, transgression and intersubjectivity. Copenhagen: Museum Tusculanum Press.

Jeffrey, C. (2010) 'Timepass: youth, class, and time among unemployed young men in India', American Ethnologist 37 (3): 465-81. 
Langevang, T. and K. V. Gough (2009) 'Surviving through movement: the mobility of urban youth in Ghana', Social and Cultural Geography 10 (7): $741-56$.

Larkin, B. (2008) Signal and Noise: media, infrastructure, and urban culture in Nigeria. Durham NC and London: Duke University Press.

Lin, A. M. Y. and A. H. M. Tong (2007) 'Text-messaging cultures of college girls in Hong Kong: SMS as resources for achieving intimacy and gift-exchange with multiple fuctions', Continuum: Journal of Media and Cultural Studies 21 (2): 303-15.

Ling, R. (2004) The Mobile Connection: the cell phone's impact on society. San Francisco CA: Morgan Kaufmann.

Ling, R. and P. E. Pedersen (eds) (2005) Mobile Communications: re-negotiations of the social sphere. London: Springer.

Mains, D. (2007) 'Neoliberal times: progress, boredom, and shame among young men in urban Ethiopia', American Ethnologist 34 (4): 659-73.

Maroon, B. (2006) 'Mobile sociality in urban Morocco' in A. Kavoori and N. Arceneaux (eds), The Cell Phone Reader: essays in social transformation. New York NY: Peter Lang.

Marshall, J. (1993) Literacy, Power, and Democracy in Mozambique: the governance of learning from colonization to the present. Boulder $\mathrm{CO}$ : Westview Press.

Mbembe, A. and J. Roitman (1995) 'Figures of the subject in times of crisis', Public Culture 7 (2): 323-52.

McIntosh, J. (2010) 'Mobile phones and Mipoho's prophecy: the powers and dangers of flying language', American Ethnologist 37 (2): 337-53.

Melkote, D. R. and H. L. Steeves (2004) 'Information and communication technologies for rural development' in C. C. Okigbo and F. Eribo (eds), Development and Communication in Africa. Oxford: Rowman and Littlefield.

Myerson, G. (2001) Heidegger, Habermas and the Mobile Phone. London: Icon Books.

Orlove, B. (2005) 'Editorial: time, society, and the course of new technologies', Current Anthropology 46 (5): 699-700.

Porter, G., K. Hampshire, A. Abane, E. Robson, A. Munthali, M. Mashiri and A. Tanle (2010) 'Moving young lives: mobility, immobility and intergenerational tensions in urban Africa', Geoforum 41 (5): 796-804.

Roesch, O. (1992) 'Renamo and the peasantry in Southern Mozambique: a view from Gaza Province', Canadian Journal of African Studies 26: 462-84.

Rungo, J. (2007) 'População mostra maturidade e as autoridades vão a reboque', Domingo (Maputo) 1329: 4-5.

Sheldon, K. E. (2002) Pounders of Grain: a history of women, work, and politics in Mozambique. Portsmouth NH: Heinemann.

Silberschmidt, M. (2004) 'Masculinities, sexuality and socio-economic change in rural and urban East-Africa' in S. Arnfred (ed.), Re-Thinking Sexualities in Africa. Stockholm: Almqvist and Wiksell Tryckeri.

Slater, D. and J. Kwami (2005) 'Embeddedness and escape: internet and mobile use as poverty reduction strategies in Ghana', < http://zunia.org/uploads/media/ knowledge/internet.pdf>, accessed 30 September 2009.

Smith, A. K. (1973) 'The peoples of southern Mozambique: an historical survey', Journal of African History 14 (4): 565-80. 
Sumich, J. (2008) 'Politics after the time of hunger in Mozambique: a critique of neo-patrimonial interpretation of African elites', Journal of Southern African Studies 34 (1): 111-25.

Vail, L. and L. White (1991) Power and the Praise Poem. London: James Currey. van der Drift, R. (2002) 'Democracy's heady brew: cashew wine and the authority of elders among the Balanta in Guinea-Bissau' in D. F. Bryceson (ed.), Alcohol in Africa: mixing business, pleasure and politics. Portsmouth NH: Heinemann.

Vigh, H. E. (2006) Navigating Terrains of War: youth and soldiering in GuineaBissau. New York NY: Berghahn Books.

Vines, A. (1991) Renamo Terrorism in Mozambique. York: Centre for Southern African Studies, University of York.

Webster, D. (1975) 'Kinship and Co-operation: agnation, alternative structures and the individual in Chopi society'. PhD thesis, Rhodes University.

Weiss, B. (2005) 'The barber in pain: consciousness, affliction and alterity in East Africa' in F. De Boeck and A. Honwana (eds), Makers and Breakers: children and youth in postcolonial Africa. Oxford: James Currey.

West, H. G. (2005) Kupilikula: governance and the invisible realm in Mozambique. Chicago IL: University of Chicago Press.

Willis, J. (2002) Potent Brews: a social history of alcohol in East Africa 1850-1999. Athens $\mathrm{OH}$ : Ohio University Press.

\section{ABSTRACT}

This article examines the ways in which young men in the city of Inhambane, southern Mozambique, harness communication to express and address experiences of constrained physical and social mobility. It starts with an analysis of a highly valued form of oral communication - bater papo - that youth, especially young men, engage in on a daily basis before turning to mobile phone use. Tying these different forms of communication together is a profound desire to claim membership of, and to participate in, a world that remains elusive for most. However, if mobile phone communication builds on pre-existent forms of communication, it takes on particular aesthetic qualities that speak of, rather than resolve, exclusion. The article argues that, while helping bridge distances in significant ways, mobile phone communication nonetheless, and somewhat ironically, also betrays young men's immobility.

Cet article examine comment les hommes jeunes d'Inhambane, ville située dans le Sud du Mozambique, se servent de la communication pour exprimer leurs expériences de mobilité physique et sociale restreinte, et y faire face. Il commence par analyser une forme très prisée de communication orale appelée bater papo que les jeunes, et notamment les hommes, pratiquent au quotidien, avant de se pencher sur l'utilisation du téléphone portable. Ces différentes formes de communication ont en commun un désir profond d'appartenir et de participer à un monde qui demeure inaccessible pour beaucoup. Si la communication téléphonique mobile se nourrit certes des formes de communication préexistantes, elle revêt cependant des qualités esthétiques particulières qui parlent de l'exclusion plutôt que de la résoudre. L'article soutient que la communication téléphonique mobile, même si elle aide à rapprocher de manière significative, trahit néanmoins aussi et assez paradoxalement l'immobilité des hommes jeunes. 